DOI: $10.31376 / 2411-5177-2019-7-20-26$

УДК $94(477)$ «1921/1929»: 26-674

Vitrynska O.V., Chernyshov V.V.

\title{
COUNTERACTION OF BELIEVING JEWS TO THE SOVIET STATE POLICY OF RESTRICTING THE USE OF HEBREW LANGUAGE IN RELIGIOUS WORSHIP AND EDUCATION (1919-20)
}

The paper focuses on counteraction of believing Jews to the soviet state policy of restricting the use of Hebrew language in religious worship. Hebrew and Yiddish were the natural languages of Ukrainian Jews over centuries. Bolshevik regime intended to remove the religious component of social life, and the Hebrew language as the language of Jewish religious books and worship.

The authors analyse the causes and sources of the conflict between the state authorities on the one hand, and the believers and the ministers of religion on the other hand; identify initiators of the restrictions, and those who put them into practice; study the laws and legislations. There was no law prohibiting the Hebrew language, but the Commissariat of Jews had proclaimed it to be a reactionary language. It meant that the Hebrew language could be taught as a foreign language only. Jewish history had not to be taught any longer at Jewish schools, and the course of Jewish literature included only the authors who wrote in Yiddish. Religious educational institutions were the subject to liquidation.

The major focus of the study is on the reaction of students of the religious schools and their parents to the restriction of teaching in Hebrew and the ways to continue the studies in the 'religious' language. The ministers of religion (rabbis, melammeds), and students of Jewish religious schools wrote petitions to the state authorities and organised strikes. Despite most cheders and yeshivas had been closed in 1920s, some of them continued working illegally yet in the early 1930s. A few teachers and students of certain yeshivas managed to immigrate to Poland.

The books in Hebrew language were confiscated from libraries and burned. Writers, poets, and playwrights were unable to publish in Hebrew. Many of them emigrated.

The actions of believers and ministers of religion had mostly insignificant impact. Only after the New Economic Policy (NEP) had been introduced, they managed to obtain the permission to publish legally in Hebrew again

Kev words: Cheder, communism, Hebrew, Judaism, soviet state, yeshiva, Yiddish.

In history of every country there are periods of radical changes, when authorities, adherent to certain ideologies, are making efforts to bring radical changes to the foundations of traditional life. People, on the one hand, are usually inert, and unwilling to bring any changes into their lifestyle, especially in area of their spiritual life. On the other hand, however, they are tending to expect that any action, undertaken by those in power, should bring some positive changes. Therefore, any effort to force a rejection of traditional values always provokes active protests. The actions, undertaken by Ukrainian Jews in response to the restrictions of use and schooling in the Hebrew language, introduced by Soviet power, were of no exception.

There are a significant number of studies, focusing on the state policy in the first years of soviet regime with respect to Judaism. There are, for instance, works of Oleh Kozerod [1], Semyon Charnyi [2], Gershon Svet [3], Joshua Rothenberg [4]. The activity of Evsektsii KP(b)U - Jewish Section of the Communist Party of Bolsheviks in Ukraine in uprooting of Judaism studied by Mordechai Altschuller and Zvi Y. Gitelman [5]. Elina Shkolnikova made an effort to trace the changes in lifestyle of little towns inhabited by Jews [6]. Anna Shternshis made a research on how people accepted and responded to actions undertaken by the authorities. Her paper Soviet and Kosher: Jewish Popular Culture in the Soviet Union, 1923-1939 [7] is based mostly on interviews with people, who lived in the Soviet state during the period between the WW1 and WW2. The reaction of religious Jews to the restrictions of use and study of Hebrew during the early soviet period, however, has never been in the focus of any particular study. 
The paper focuses on actions, undertaken by religious Jews in order to protect their sacred language and the methods enabling to detour the prohibition. The main objective of the paper is to specify the sources and causes of the conflict; to identify the initiators of the restrictions and those, who put them into practice; to investigate the legislation; to study the attitude of religious school pupils and their parents towards the prohibition to teach in the Hebrew language, and ways how to continue teaching in the language of their religion; to analyse the destiny of writers who wrote in Hebrew in Ukraine.

Over a few centuries the natural languages of Jewish people in Ukraine were Hebrew and Yiddish. Having come into power Bolsheviks began "bringing into masses" the ideology of communism, which presupposed the complete uprooting of existing structure of social consciousness, including its religious component. God's commandments should have been removed in order to give the place to the communist theory. The attack on religion was the full-scale offensive. Every kind of religion was subject to extermination. Judaism was of no exception.

Being the language of ancient sacral texts, Hebrew became subject to the policy of uprooting, which had been introduces on a regular basis within the context of anti-Judaic policy in the early years of soviet regime. The supposed alternative to the religious culture should become a new culture of Yiddish as the only Jewish secular language.

The conflict between the adherents of Hebrew, on the one hand, and Yiddish, on the other hand, was not new, it took place yet in the Russian Empire. It is often called a "Kulturkampf" [8]: a struggle of cultures. The ideologists of confrontation were Zionists. Basing on the idea that Hebrew had been the initial language of Jewish people, and it was simultaneously used by different communities of Jewish Diaspora, Zionists believed that the use of Hebrew would become one of the most powerful means for renewing the Jewish spirit as soon as the time of exile would be over and the People would eventually reunite in the Promised Land [9]. Zionists considered Yiddish as a language of exile, the jargon of Galut

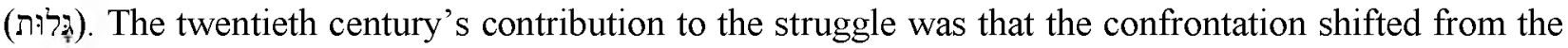
cultural plane to political one. Bolshevik-Jews considered the struggle with Hebrew as an opposition to the Zionist ideology.

The campaign against Hebrew in the Ukraine was initiated by Hebrew section of Communist Party of Bolsheviks of Ukraine. Jewish communists stated that Yiddish is the language of proletarian masses, as Hebrew is used by clericals, Zionists, and nationalistic bourgeoisie. However, the workers of Jewish section appreciated Yiddish merely as a channel for spreading of Bolshevik ideology among Jewish people, being absolutely indifferent to it as a characteristic of unique national identity. Therefore they counted that Yiddish must necessarily exist only until the time when Jews would have fully mastered Russian [8]. Ukrainian and Russian communists did not interfere in the struggle, though the cause of such hatred towards Hebrew from the side of Jewish section had not been always sufficiently clear for them.

Soviet authorities officially had never prohibited Hebrew as a language on the level of legislation. Although, at the insistence of Jewish Section, the Commissariat of Jews declared that Hebrew is a language of reaction. On 2 July 1919 People's Commissariat of Education issued a resolution which contained a number of statements that, first, Hebrew had never been a spoken language of Jewish people, therefore it should not be recognised as a language of ethnic minority, and consequently should be learnt as a foreign language; second, the teaching in Hebrew in the primary schools should be stopped immediately, and up to the new school year the school councils should decide which spoken language, recognised by the state, they wish to teach; pupils of the secondary school, who had already commenced schooling in Hebrew, should be permitted to continue and finish their education [10, арк. 31]. Books, written in Hebrew should be confiscated from libraries and burnt out. The biggest bonfires of such books blazed in Kharkiv and Kyiv [11].

Closings of schools which taught in Hebrew began in the Ukraine in 1919. However those actions of local authorities were not on a mass scale. Moreover, on 2 July 1919, Bureau of Jewish Section made a decision: "All actions of requisition, confiscation, forcible school closings, etc., 
whosoever had undertaken them with respect to schools on the language of Ivris should be withdrawn". The schools that had been closed before were reopened.

In October 1920, People's Commissariat of Education issued a resolution on the use of Yiddish as a language for teaching in Jewish schools [12, c. 28]. It had stated that the mother tongue of Jewish population had been Yiddish not Hebrew, and the teaching in the latter was prohibited. Hebrew had to be excluded from the list of compulsory disciplines in the mixed labour schools, as Yiddish was proclaimed to be the only teaching language in the Jewish schools of all types within the Republic.

The Jewish community did not agree with the prohibition of Hebrew as a school language at once. In order to express their protests, pupils and their parents wrote repeatedly petitions to the state authorities [13, арк. 160], organised strikes. Thus, the strike committee of Jewish pupils of the city of Odessa in 1920, explained that due to the prohibition of Hebrew the children are deprived of opportunity to participate in Jewish national culture, called a strike from 14 to 16 April and encouraged all Jewish pupils not to go to school on those dates $[14$, c. 67-68]. One of the ways to keep Hebrew on was spreading of leaflets, during a census of population, with the call to state Hebrew as their mother tongue. But those actions had not succeeded, and the school teaching was carried on in Yiddish.

The work for uprooting Hebrew was carried along with the liquidation of religious education. Soviet power permitted private persons to open theological courses to teach religious subjects in Hebrew only for adults; under the condition that not a single general subject would be taught in Hebrew [15, арк. 123; 16, арк. 206]. But such courses were not popular among Jews.

The mass cheder, yeshiva, and Talmud-Tor closing campaign started in Ukrainian SSR in 1922 [17, арк. 2; 18, арк. 33-34, 47-50; 19, арк. 15a]. In spite of many Jewish educational institutions had been liquidated, some of them continued their activity as a clandestine practice up to the middle 1930s. Quite often only the immigration to another country allowed continuing teaching in yeshiva. Thus, for instance, the yeshiva chiefs of Zhytomyr, Kyiv, and Berdychiv along with their students moved illegally to neighbouring Poland [20].

However the teaching of Hebrew as a separate subject in schools was allowed. Thus, in July 1922, the head of Liquidation department of People's Commissariat of Justice Ivan Sukhopluev instructed Donetsk liquidation commission that cheders should be closed all around the province of Donetsk, but Hebrew could be allowed to be introduced and taught as a separate subject in national Jewish schools, organised by the Section of People's Education in cases there is no opportunity to limit with organising separate classes of Hebrew for Jews in Labour School that is common to all citizens [16, арк. 206].

Soviet Jewish school could be counted national only due to the fact that the teaching was held in Yiddish. Hebrew was taught as a separate subject, as well as the course of national literature, in which

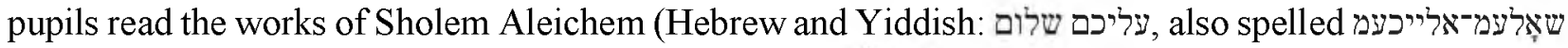
in Soviet Yiddish), Mendele Mocher Sforim (Hebrew: ספרים מוכר מנדלי, Yiddish: ספרים מוכר מענדעלע), and soviet writers. The history of Jews had been removed from the school curriculum, only in the general course of history, pupils had an opportunity to learn something about the class struggle of the Jewish poor against czarism [6].

Teaching of Hebrew remained in the higher school. A course of Hebrew was delivered - under the strictest supervision - for future archaeologists, linguists, and those who specialised on the Ancient East.

There were many writers, poets, and playwrights in the Soviet Union, who had been writing in Hebrew, but no one of them had been allowed to publish their works. Only a few of them were allowed to emigrate. Thus, renowned Hebrew writers Hayim Nahman Bialik (Hebrew: ביאליק נחמן חיים), Shaul

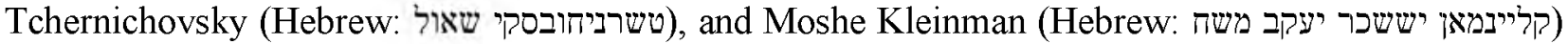

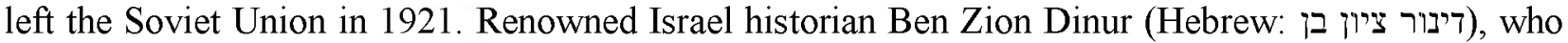
was born in Ukraine, three years before his immigration to mandated Palestine, had published in Kyiv in Hebrew a book The History of Israel [21]. This work became the first part that opened a long train of his lifelong researches: search and classification of sources and documents, basing on which he endeavoured to build an uninterrupted and organic history of Jewish nation [22, p. 87]. In 1930s, the 
scholar held the position of lecturer at Jerusalem University. The sequel of The History of Israel titled The Israel in Exile was published in 1926 in Hebrew in Tel-Aviv [23]. Baruch Spielberg, who remained to live in Berdychiv, was very much upset because he was the only man in the town who wrote in Hebrew, and there was no learned person, whom he could talk to in order to discuss all his creative ideas [9, c. 112]. There were those, who continued writing prose and poetry in Hebrew, though, even without getting it published, it was dangerous.

Hebrew was being uprooted everywhere. There were efforts of purifying Yiddish from Hebrew lexemes, which made up approximately 20 per cent of the entire language vocabulary. In order to do this there had been undertaken a radical reform of Yiddish orthography. Transcription of the words of Hebrew origin was changed with respect to Yiddish phonetics. Ending letters, which had been written in a different way than in the middle of words, now should be rejected. Soviet literary Yiddish varied significantly from the foreign version, and became unintelligible for the reader $[8, \mathrm{c} .308-309 ; 9$, c. $112]$.

The situation softened a bit as the New Economic Policy (NEP) had been introduced. Little private typographies published religious books and Jewish calendars in Hebrew. In Poltava, Berdychiv, and Zhytomyr printed Siddurim (Hebrew: סדורים - prayer books), Tehillim (Hebrew: קְּה - Psalms),

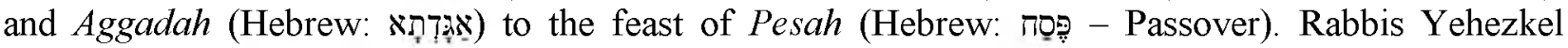
Abramsky (Hebrew: אברמסקי יחזקאל) and Shlomo Yosef Zevin (Hebrew: זווין יוסך שלמה published


book by Rabbi Yitzchok Isaac ben Dov Ber Krasilschikov [24, c.191-192]. During 1927-28, in the Soviet Union, synagogues and orthodox families received no less than 100000 religious books in Hebrew. In the late 1920s the printing was stopped, and in the early 1930s not a single book appeared in Ukraine in Hebrew.

Reading prayers in Hebrew was strictly forbidden in functioning houses of prayer and synagogues. Studying the interrelations between the state and Jewish communities Gershon Svet compares the Soviet linguistic policy with respect to Jews and to believers of other religions, finally drawing a conclusion of linguistic discrimination of the Jews [3, c. 221].

By this time there was a mass breaking of young people with traditional Jewish lifestyle and Hebrew as one of its components. It was not caused by the efforts of Jewish sections, but by the change of environment and the mode of young people's life. Having moved from little local towns to big cities, the new generation of Jews got into non-Jewish environment, where keeping traditions and Jewish religious ceremonies in general as much as the use of Hebrew as a religious language in particular was complicated, unnecessary, and unpopular at once [25].

Thus we may conclude that the actions of Bolshevik power on uprooting Hebrew provoked counteractions of people. Ukrainian Jews petitioned to local and higher authorities, asking to be allowed to retain Hebrew as the language of education and prayers. Cheders that kept teaching in Hebrew went underground and continued their clandestine activity during the 1920s, the heads of yeshivas, along with their students, had to emigrate. Writers who wrote in Hebrew did not have any opportunity to get published and spread their works in the soviet Ukraine. They had to leave the country, and those who remained had to cease their activity.

In the 1920s, Ukrainian Jews undertook active efforts to defend their language, but in this struggle the Bolsheviks proved to be stronger.

The future researches on reaction of Jewish believers to restrictions for the use of Hebrew, as well as other measures for liquidation of Judaism and religious worldview, presuppose references to files, preserved in the State Sectoral Archive of the Security Service of Ukraine, the State Archive of Russian Federation, Russian State Archive of Socio-Political History, the oral evidences of immediate eyewitnesses, as much of Jewish origin as ones of non-Jewish origin, who were the neighbours of the former. Examining the treated question, it is important to identify previously unpublished facts of counteractions to soviet atheistic policy, the analysis of protest dynamics in the 1920-30s, and the punishment of protesters. 
1. Козерод О. В. Євреї України в період нової економічної політики: 1921-1929 рр. / О. В. Козерод - Київ: СПД Савчнна, 2003. - $313 \mathrm{c}$.

2. Чарный С. А. Государственная политика в отношении еврейских религиозных общин в период «оттепели»: 1953-1964: дис. ... канд. ист. наук: 07.00 .02 «Отечественная история» / Чарный Семен Александрович. - Москва, 2008. - 215 л.

3. Свет Г. Еврейская религия в Советской России / Гершон Свет // Книга о русском еврействе: 1917-1967. Иерусалим: «Гешарим», М.: РПО «Мосты культуры»; Минск: ООО «МЕT», 2002. - С.215-221.

4. Rothenberg J. The Jewish Religion in the Soviet Union. / Joshua Rothenberg. - New York: KTAV Publishing House, 1971. $-242 \mathrm{p}$.

5. Gitelman Z. Y. Jewish Nationality and Soviet Politics: The Jewish Sections of the CPSU. 1917-1930. / Zvi Y. Gitelman. - Princeton, New York., 1972. - 573 p.

6. Школьникова Э. Трансформация еврейского местечка в СССР в 1930-е годы [Электронный ресурс] / Элина Школьникова. - М., 1996. - 44 с. - Режим доступа : http://jhistory.nfrman.com/lesson9/1930.htm. Название с экрана. - Дата обращения: 31.03.2008.

7. Shternshis A. Soviet and Kosher: Jewish Popular Culture in the Soviet Union, 1923-1939 / Anna Shternshis. Bloomington: Indiana University Press, 2006. -252 p.

8. От Авраама до современности / Под ред. Д. Фишмана, Б. Высоцки. - М.: РГГУ, 2002. - 389 с.

9. Гительман Ц. Беспокойный век: Евреи России и Советского Союза с 1881 г. до наших дней / Цви Гительман. - М.: Новое литературное обозрение, 2008. - 512 с.

10. Центральний державний архів громадських організацій України (ЦГАОО У). - Ф. 1. - Оп. 20. - Д. 91.

11. Жидовецкий М. Сборник статей по еврейской истории и литературе / М. Жидовецкий [Электронный peсурс]. Режим доступа: //https:www. zezam.org/publications/7/1. - Название с экрана.

12. Коммунистическая власть против религии Моисея: Документы 1920-1937 и 1945-1953 гг. [Сб. докум.]/

Сост. В. Ю. Васильев и др. - Вып. 2. - Винница: Глобус-пресс, 2005. - 384 с.

13. ЦГАОО У. - Ф. 1. - Оп. 20. - Д. 2007.

14. Еврейский вопрос: поиски ответа: Документы 1919-1926 гг. [Сб. докум.] / Сост. В. Ю. Васильев и др. Вып. 1. - Винница: Глобус-пресс, 2003. - 352 с.

15. Центральний державний архів вищіх органів влади України (ЦГАВОВ У). - Ф. 8. - Оп. 1. - Д. 1216. - Л. 123.

16. ЦГАВОВ У. - Ф. 8. - Оп. 1. - Д. 1217. - Л. 206.

17. ЦГАВОВ У. - Ф. 5. - Оп. 1. - Д. 2254. - Л. 2.

18. ЦГАОО У. - Ф. 1. - ОП. 20. - Д. 5131. - Л. 33-34; 47-50;

19. ЦГАОО У. - Ф. 1. - ОП. 20. - Д. 1533. - Л. 15a.

20. Вітринська О. В. Юдейські заклади освіти в контексті радянської політики боротьби з релігією в 192030-х роках в Україні / Олена Вітринська // Проблеми історії України: факти, судження, пошуки. - 2007. - № 16. - C. 129-141.

21. Dinur, Ben-Zion (Dinaburg), History of Israel. - Kiev: Society of Distributors of Education in Israel, 1918 (in Hebrew).

22. Занд Ш. Кто и как изобрел еврейский народ / Шломо Занд; авториз. перевод с иврита М. Урицкого. М.: Эксмо, $2010-544$ с.

23. Dinur, Ben-Zion (Dinaburg), Israel in Exile. - Tel Aviv: Dvir, 1926 (in Hebrew).

24. Кандель Ф. Книга времен и событий. Т. 3. История евреев Советского Союза (1917-1939) / Феликс Кандель. - М.: Мосты культуры, 2002. - 488 с.

25. Измайлова Л. Отражение компартийной политики в Украине на еврейской семье /Лина Измайлова // Сврейський світ. -2004 . - С. 66-76.

Предметом розаляду даной роботи є направлена на захист релігійной мови діяльність віруючих свреӥв і методи уникнення заборони ї̈ використання.

Протягом кількох століть національними мовами євреїв Украйни були іврит й їдии. Більиовицький режим передбачав знищення попередньої релігійної складової, а значить і івриту, як мови богослужсння та священних книг юдеӥв.

Автори проаналізували причини та джерела конфлікту влади з віруючими і служстелями культу; визначили ініціаторів обмежень і тих, хто їх реалізовував; вивчили законодавчу базу антиюдейськой політики. На законодавчому рівні іврит не був заборонений. Єврейський комісаріат лиие оголосив його «реакційною мовою». Цце означало, цуо давньоєврейська мова могла використовуватися для навчання лише як іноземна. Історія науіональной мениини була вилучена із икільной програми сврейських икіл, у курсі сврейськой літератури твори вивчалися лише на їдиі. 
Основна увага в роботі була приділена дослідженню ставлення учнів релігійних икіл та їх батьків до заборони викладання івритом і способів продовжсння навчання релігійною мовою. Служстелі культу, віруючі та учні єврейських икіл писали скарги до органів влади і організовували страйки. Не дивлячись на те, ио хедери та єииви були заборонені на законодавчому рівні на початку 1920-х, деякі з них продовжували нелегально праџювати до периої половини 1930-х років. Викладачі та учні декількох сиив емігрувати до Польщі.

Написані давньосврейською мовою книги вилучали з бібліотек і спалювали. Письменники, поети і драматурги не мали можливості публікуватися івритом. Багато з них емігрували.

Протидія віруючих і служителів культу мала незначний результат. Лиие в період нової економічної політики вони змогли добитися дозволу видавати книги давньосврейською мовою.

Ключові слова: юдайзм, іврит, їии, комунізм, радянська влада, хедер, єиива.

Предметом рассмотрения в данной работе является деятельность верующих евреев, направленная на защиту своего религиозного языка и методы обхода запрета его использования. Проанализированы причины и источники конфликта власти с веруюиими и служсителями культа; определены инициаторы ограничений и те, кто их реализовывал; изучена законодательная база. Основное внимание уделено исследованию отночения учеников религиозных икол и их родителей к запрету преподавания на иврите и способов продолжения обучения на "религиозном» языке. Проанализирована судьба ивритских писателей Украины.

Ключевые слова: иудаизм, иврит, идии, коммунизм, советская власть, хедер, ечива.

1. Kozerod O. V. Evreji Ukrajini v period novoj ekonomichnoji politiki: 1921-1929 rr. / O. V. Kozerod - Kyiv: SPD Savchina, 2003. $-313 \mathrm{~s}$.

2. Charnyj S. A. Gosudarstvennaja politika v otnoshenii evrejskih religioznyh obshhin v period «ottepeli»: 19531964: dis. ... kand. ist. nauk: 07.00.02 «Otechestvennaja istorija»/ Charnyj Semen Aleksandrovich. - Moskva, 2008. $-215 \mathrm{~s}$.

3. Svet G. Evrejskaja religija v Sovetskoj Rossii / Gershon Svet // Kniga o russkom evrejstve: 1917-1967. Ierusalim: «Gesharim», M.: RPO «Mosty kul'tury»; Minsk: OOO «MET», 2002. - S.215-221.

4. Rothenberg J. The Jewish Religion in the Soviet Union. / Joshua Rothenberg. - New York: KTAV Publishing House, 1971. $-242 \mathrm{p}$.

5. Gitelman Z. Y. Jewish Nationality and Soviet Politics: The Jewish Sections of the CPSU. 1917-1930. / Zvi Y. Gitelman. - Princeton, New York., 1972. - 573 p.

6. Shkol'nikova Je. Transformacija evrejskogo mestechka v SSSR v 1930 -e gody [Jelektronnyj resurs] / Jelina Shkol'nikova. - M., 1996. - 44 s.: http://jhistory.nfrman.com/lesson9/1930.htm. 31.03.2008.

7. Shternshis A. Soviet and Kosher: Jewish Popular Culture in the Soviet Union, 1923-1939 / Anna Shternshis. Bloomington: Indiana University Press, 2006. -252 p.

8. Ot Avraama do sovremennosti / Pod red. D. Fishmana, B. Vysocki. - M.: RGGU, 2002. $-389 \mathrm{~s}$.

9. Gitel'man C. Bespokojnyj vek: Evrei Rossii i Sovetskogo Sojuza s 1881 g. do nashih dnej / Cvi Gitel'man. - M.:

Novoe literaturnoe obozrenie, 2008. $-512 \mathrm{~s}$.

10. Central'nyj derzhavnyj arhiv gromads'kyh organizacij Ukrajiny (CGAOO U). - F. 1. - Op. 20. - D. 91.

11. Zhidoveckij M. Sbornik statej po evrejskoj istorii i literature / M. Zhidoveckij: /https:www. zezam.org/publications/7/1.

12. Kommunisticheskaja vlast' protiv religii Moiseja: Dokumenty 1920-1937 i 1945-1953 gg. [Sb. dokum.] / Sost.

V. Ju. Vasil'ev i dr. - Vyp. 2. - Vinnica: Globus press, 2005. - 384 s.

13. CGAOO U. - F. 1. - Op. 20. - D. 2007.

14. Evrejskij vopros: poiski otveta: Dokumenty 1919-1926 gg. [Sb. dokum.] / Sost. V. Ju. Vasil'ev i dr. - Vyp. 1. - Vinnica: Globus press, 2003. - 352 s.

15. Central'nyj derzhavnyj arhiv vishhih organiv vlady Ukrajiny (CGAVOV U), - F. 8. - Op. 1. - D. 1216. - L. 123.

16. CGAVOV U. - F. 8. - Op. 1. - D. 1217. - L. 206.

17. CGAVOV U. $\neg-$ F. 5. - Op. 1. - D. 2254. - L. 2.

18. CGAOO U. - F. 1. - Op. 20. - D. 5131. - L. 33-34; 47-50;

19. CGAOO U. - F. 1. - Op. 20. - D. 1533. - L. 15a.

20. Vitryns'ka O. V. Judejs'ki zaklady osvity v konteksti radjans'koji polityky borot'by z religieju v 1920-30-h rokah v Ukrajiny / Olena Vitryns'ka // Problemy istorijy Ukrajiny: fakty, sudzhennja, poshuky. - 2007. - № 16. - S. 129141. 
21. Dinur, Ben-Zion (Dinaburg), History of Israel. - Kiev: Society of Distributors of Education in Israel, 1918 (in Hebrew)

22. Zand Sh. Kto i kak izobrel evrejskij narod / Shlomo Zand; avtoriz. perevod s ivrita M. Urickogo. - M.: Jeksmo, $2010-544 \mathrm{~s}$.

23. Dinur, Ben-Zion (Dinaburg), Israel in Exile. - Tel Aviv: Dvir, 1926 (in Hebrew).

24. Kandel' F. Kniga vremen i sobytij. T. 3. Istorija evreev Sovetskogo Sojuza (1917-1939)/Feliks Kandel'. - M. Mosty kul'tury, 2002. - $488 \mathrm{~s}$.

25. Izmajlova L. Otrazhenie kompartijnoj politiki v Ukraine na evrejskoj sem'e /Lina Izmajlova // Evrejs'kyj svit. 2004. - S. 66-76.

(C) Вітринська О. В., Чернишов В. В., 2019

Стаття надійшла до редколегії 23.09.2019 p. 